THE JOURNAL OF ECONOMIC HISTORY

VOLUME 77

March 2017

NUMBER 1

\title{
Women's Income and Marriage Markets in the United States: Evidence from the Civil War Pension
}

LAURA SALisBURY

Under the Civil War pension act of 1862, Union Army widows were entitled to pensions; however, they lost these pensions if they remarried. Using a database compiled from widows' pension files, I estimate the effect this had on widows' remarriage decisions. I find that receiving a pension lowered the hazard rate of remarriage by 25 percent, which implies an increase in the median time to remarriage of 3.5 years. Among older women, the effect is greater. These results suggest that many Union Army widows faced highly unfavorable marriage prospects.

$\mathrm{T}$ The American Civil War had large and lasting demographic impacts. The Civil War was associated with tremendous loss of life: military deaths were the greatest in American history, exceeding those in WWII by 50 percent (Vinovskis 1989). Moreover, the Civil War gave rise to America's first large social insurance program, the Union Army Pension, which altered retirement behavior, family living arrangements, and longevity (Costa 1995, 1997; Eli 2015). One obvious demographic

The Journal of Economic History, Vol. 77, No. 1 (March 2017). (C) The Economic History Association. All rights reserved. doi: 10.1017/S0022050717000067

Laura Salisbury is Assistant Professor, Department of Economics, York University, Vari Hall \#1092, 4700 Keele St., Toronto, ON M3J 1P3, Canada. E-mail: 1salisbu@yorku.ca.

I thank Robert Margo, Claudia Olivetti, Daniele Paserman, and Carola Frydman for invaluable advice. Comments from Ran Abramitzky, Joseph Burton, Louis Cain, Dora Costa, Shari Eli, Joseph Ferrie, Claudia Goldin, Frank Lewis, Aloysius Siow, Richard Steckel, and two anonymous referees, as well as seminar participants at the National Bureau of Economic Research, University of Montreal, Purdue, Boston University, Stanford, UCLA, Harvard, Northwestern, CPE-University of Chicago, Toronto, Guelph, and the annual meetings of the Economic History Association are also gratefully acknowledged. I also thank Noelle Yetter at the CPE, and the helpful and knowledgeable staff at the National Archives in Washington, DC. I acknowledge financial support from the National Science Foundation (SES-1227471), the Economic History Association, and Boston University. Any errors are mine. 
consequence of the Civil War was a reduction in the male-female ratio, which, in principle, would have adversely affected women's marriage prospects. J. David Hacker, Libra Hilde, and James Holland Jones (2010) look for evidence of a "marriage squeeze" in the years following the Civil War and find little indication that women had difficulty marrying. In this article, I explore the value of marriage to Union Army widows, an especially vulnerable group of women during this period. In particular, I evaluate the extent to which the Civil War pension discouraged these widows from remarrying. My results suggest that, despite the frequency of remarriage, these women did not value marriage very highly; this raises the possibility that the absence of a decline in the quantity of marriages immediately after the Civil War masks a decline in the quality of marriages.

The Civil War pension was a federal program introduced in 1862 to compensate wounded Union Army veterans and their dependents. A widow was entitled to receive a pension if her husband died as a direct result of his military service; however, she lost her right to the pension if she remarried. As such, this pension functioned in the marriage market in a way that is analogous to unemployment insurance benefits in the labor market. Search models of the marriage market predict that such an income shock raises the value of being single relative to the value of being married, thus raising a woman's reservation match quality. Under random matching, this will lower the probability that any given proposal of marriage is deemed suitable, which will tend to delay marriage. ${ }^{1}$ The magnitude of this effect depends in part on how the value of the income shock compares with the value of a typical marriage. For example, if marriages are typically much more valuable than a pension, then receiving a pension should not dramatically change the rate of remarriage. However, if the pension is more valuable than many marriage proposals, it should deter women from accepting a significant number of matches, thus generating a sizable effect on the remarriage rate. ${ }^{2}$

If receiving a pension significantly lowered the rate of remarriage among widows who applied for relief, this is informative about the

\footnotetext{
${ }^{1}$ See Rogerson, Shimer, and Wright (2005) for a survey of basic search models. See Weiss (1997) for a review of search models applied to marriage markets. Gould and Paserman (2003) and Loughran (2002) use a search framework to investigate the effect of wage inequality on marriage rates.

${ }^{2}$ This reasoning is based on a simple search model (Rogerson, Shimer, and Wright 2005; Mortenson 1986), in which the hazard rate of remarriage is equal to the arrival rate of proposals multiplied by the probability of encountering an acceptable match. The more probability mass is contained between a person's pre- and post-pension reservation match qualities, the greater the effect of the pension on the rate of remarriage.
} 
marriage prospects these women faced. At eight dollars per month, the pension was less than half the monthly income of a typical farm laborer in 1870 (Margo 2000), so it was hardly enough to comfortably support a family. Thus, a large effect of this pension on the remarriage rate suggests that these women were routinely entering into marriages of low value. This, in concert with other related literature, is informative about marriage in the aftermath of the Civil War. The large number of male casualties lowered the ratio of marriageable men to marriageable women. Nonetheless, Hacker, Hilde, and Jones (2010, p. 49) find little evidence of a "marriage squeeze" for women, noting that, instead of forgoing marriage entirely, women may have "relaxed their standards of acceptable partners." In principle, this may be driven by one of two things: (1) women generally valued marriage very highly; or (2) women generally had poor outside options. A substantial negative effect of receiving a (small) pension on the probability of remarriage suggests that Union Army widows who applied for pensions did not, as a rule, value the marriages available to them very highly; thus, the relatively high remarriage rate in this population must be driven at least in part by a lack of good economic alternatives.

The notion that Union Army widows faced both poor marriage prospects and poor alternatives to marriage is intuitive. In an environment with poor labor market prospects for women and limited social provision, unmarried widows typically relied on extended family for support; failing that, many found low wage employment in domestic service (Schwartzberg 2004). Those with young children were often faced with the prospect of placing them in alternative care, such as orphanages, due to a lack of means to support them (Moehling 2002). At the same time, it is conceivable that these women faced especially poor marriage prospects following the Civil War. Fewer men in the marriage market meant at least a weak reduction in potential match quality from the perspective of women, as well as a reduction in women's bargaining power. Hacker, Hilde, and Jones (2010) show that the types of men women married changed in the aftermath of the Civil War. Similarly, Ran Abramitzky, Adeline Delavande, and Luis Vasconcelos (2011) show that the negative shock to the male-female ratio in France after WWI caused women to marry poorer men.

I compile a novel database containing information on widows' pension applications and subsequent marriages from the Civil War pension files at the National Archives in Washington, DC. To assess the extent to which pensions caused widows to delay remarriage, I use variation in the timing of pension decisions, or pension processing times. Because 
pension amounts were standardized, processing times provide the most plausibly exogenous variation in pension income in my sample. I estimate a proportional hazards model of remarriage in which the rate of remarriage is allowed to shift at the moment a pension is granted. As such, I estimate a treatment effect of transitioning from having a pending claim to having an accepted claim. Because of discounting and uncertainty about the eventual outcome of a claim, having a claim granted would have represented a real positive utility shock. However, because the probability of rejection was quite low, this utility shock is likely driven by the increase in liquidity, or decline in acute financial distress, that accompanied an accepted pension application.

One concern with this approach is the possible endogeneity of pension processing times to marital outcomes. This is largely due to sample selection, which is generated by the decision to apply for a pension. Women whose pensions took a long time to process tended to be those with ambiguous claims, and those who chose to incur the cost of applying for a pension even though their claims were ambiguous may have been systematically different from those who applied with straightforward claims. To address this, I exploit the fact that my treatment variable is a duration variable, which provides more information than is available in a standard cross-sectional setting. If the proportional hazards assumption holds, then apparent changes in the effect of covariates on the rates of remarriage and pension receipt offer sufficient information to identify the distribution of unobserved heterogeneity in these two risks. Identification of the joint distribution of these unobserved heterogeneity terms allows for identification of the causal effect of receiving a pension on the rate of remarriage (Abbring and Van den Berg 2003a, 2005).

I find that receiving a pension caused the rate of remarriage to drop by 25 percent, implying an increase in the median time to remarriage of 3.5 years. Moreover, I find that this effect is heterogeneous: the effect of the pension increases in magnitude with the widow's age and number of children. The results suggest that some widows - particularly older widows with more young children - were entering into marriages of very low value during this period, likely out of financial necessity. This type of behavior is generally difficult to quantify; demonstrating how unfavorable marriage could be for certain women during this period is a major contribution of the article. My results also raise the possibility that, while the Civil War did not substantially lower marriage rates, it may have lowered the quality of marriages many women entered into, particularly poor women with the fewest alternatives. This is another potential demographic cost of the Civil War, which has received little attention in the literature to date. 


\section{RELATED LITERATURE: MARRIAGE AND WOMEN'S ECONOMIC OPPORTUNITIES}

This article contributes to a literature on the relationship between women's income and marriage rates. Upon marriage, men have historically specialized in market work while women have specialized in home production. Thus, economic opportunities for men have "complemented" marriage, while economic opportunities for women have "substituted" for marriage (Becker 1991). The historical literature on income and marriage rates has largely focused on men's income (or family income). In particular, the decline in fertility and growth in the average age at first marriage that occurred during the nineteenth century (Haines 1996) has been attributed to declining land availability, which increased the cost of household formation for young couples (Easterlin 1973).

A small number of studies link women's economic opportunities to delayed marriage or fertility before the twentieth century. Hacker (2008) offers evidence from the 1860 census that women tended to marry later in areas in which economic opportunities for women were greater; this is measured by local unmarried female labor force participation. Marianne Wanamaker (2012) links industrialization to declining fertility in the nineteenth century, with a focus on fertility within marriage. While marriage is not the focus of her book, Claudia Goldin (1990) notes the effect of poor labor market expectations on women's desire for marriage. She quotes a 1910 U.S. government report on women and industry, which argued that, "In most cases, probably, woman's expectation of marriage is responsible for her lack of skill, but in some instances, doubtless, her enforced lack of skill is responsible for her longing for marriage" (p. 95). Goldin (1997) also indirectly links economic opportunities to delayed marriage by noting a tendency for women's education and marriage to be mutually exclusive. She describes a "stark set of alternatives between career and family" (p. 1) for women attending college in the early twentieth century, noting that approximately half of women graduating in 1910 were childless. Similarly, women's colleges in the late nineteenth century were labeled "spinster factories" (Monahan 1951, p. 242).

The modern literature on women's income and marriage markets is more extensive. In general, measuring the effect of women's income on their marital outcomes is challenging, due to the possibility of reverse causality. As such, much of the empirical literature on this topic is descriptive, demonstrating a negative correlation between women's income or career opportunities and marriage rates. An article that deals explicitly with causality is by Francine Blau, Lawrence M. Kahn, and Jane Waldfogel (2000), who study the effect of city-wide labor market 
conditions on marriage rates. They find that better female labor markets tend to decrease marriage rates, while better male labor markets tend to increase them. Other work has used experimental or quasi-experimental evidence to assess the impact of women's income on their propensity to marry. For example, Scott Hankins and Mark Hoekstra (2011) find that winning the lottery reduces the probability of marriage for single women. Using data from a randomized experiment in India, Robert Jensen (2012) shows that increasing women's opportunities in the labor market causes them to delay marriage and childbearing. Mark Rosenzweig (1999) studies the effect of the Aid to Families with Dependent Children (AFDC) program on marriage and out-of-wedlock childbearing for young women, and he finds that AFDC benefits encourage fertility outside marriage. Michael Baker, Emily Hanna, and Jasmin Kantarevic (2004) find a significant negative effect of marriage penalties on remarriage, which they identify through the removal of marriage penalties from the public pension system in Canada during the 1980s. Michael J. Brien, Stacy Dickert-Conlin, and David A. Weaver (2004) find that American widows and widowers delayed remarriage until after the age of 60 due to the marriage penalty built into Social Security before 1979.

\section{INSTITUTIONAL BACKGROUND: WIDOWS AND THE CIVIL WAR PENSION LAW}

The original Civil War pension law, called the General Law, was passed on 14 July 1862. This act provided compensation for soldiers and the dependents of soldiers who had fought honorably for the Union and who had been wounded in such a way that they were unable to work. Over time, this pension system expanded into a form of old-age security for Union Army veterans and their families. Pension expenditures grew from 29 million dollars in 1870 to 160 million dollars by 1910 , covering almost one million veterans and their dependents (Linares 2001). It is generally considered America's first large-scale social assistance program (Skocpol 1995).

Eligibility for a widow's pension under the General Law depended on three main criteria. A widow was entitled to a pension if she did not remarry and her husband had served honorably in the Union army and died of a disease or injury sustained in the service. The qualifying widow of a private in the Union Army was entitled to eight dollars per month plus two dollars per minor child (under the age of 16) beginning on 25 July $1866 .{ }^{3}$ To give a sense of the size of this income, a typical daily wage

\footnotetext{
${ }^{3}$ Glasson (1900, 1918); Song (2000). Officers' widows were entitled to a larger pension, but the Union Army database contains only privates.
} 
for a common laborer in the north was approximately one dollar in 1860 and two dollars in 1870; including room and board, a farm worker would typically make 11 to 15 dollars per month in 1860 and 18 to 20 dollars per month in 1870 (Margo 2000). If a widow remarried, she lost her right to a pension. Entitlement to the pension then passed to the soldier's minor children, who were allowed to receive it until the youngest turned 16 .

The pension law as applied to widows was amended at various times. The most significant amendment was the act of 27 June 1890, which allowed widows to claim pensions if their husbands had served honorably for at least 90 days in the Union Army, regardless of how they died. However, unlike applicants under the General Law, a widow applying under this amendment had to demonstrate that she was "dependent upon her daily labor for support" (Linares 2001). Under the act of 14 July 1862 , widows permanently lost their right to a pension if they remarried. However, later changes to the General Law altered this somewhat. As of 7 June 1888, a widow who had remarried could apply for a General Law pension in arrears, commencing on the date of her first husband's death and terminating on the date of her remarriage. On 3 March 1901, a widow who was eligible under the General Law but had remarried was allowed to be restored to the pension rolls after her new husband died, provided she had never divorced this second husband, and she was needy. It became progressively easier for remarried widows to be restored to the rolls through the 1920s (Glasson 1900).

The process of applying for pensions was costly and time consuming. In contrast to soldiers who filed pension claims, widows did not need to be examined by a surgeon; however, they were required to provide a great deal of evidence in support of their claims. A widow had to appear before a court of record. If she lived more than 25 miles from a court of record, she could appear before a pension notary stationed in her locality (Oliver 1917). Here, she would make her declaration, which involved filling out a form in the presence of witnesses. The instructions attached to this form outline the information and documents she was required to furnish:

She must prove the legality of her marriage, the death of her husband, and that she is still a widow. She must also furnish the names and ages of her children under sixteen years of age, at her husband's decease, and the place of their residence... The legality of the marriage may be ascertained by the certificate of the clergyman who joined them in wedlock, or by the testimony of respectable persons having knowledge of the fact, in default of Record evidence. (Widow's Certificate No. 8,336).

This evidence was mailed to the pension bureau in Washington, DC, where claims were adjudicated. This adjudication process involved 
obtaining the soldier's military record from the War Department. If a widow could not prove that she was legally married to the soldier or that his death was a direct result of his military service, her claim would be rejected.

In many instances, claimants hired attorneys to prosecute their claims. The quality of the attorney could have a dramatic effect on the speed with which a claim was processed; there are ample instances of claims pending for years because of attorney neglect, a problem well known to the pension board. The 1883 annual report of the pension commissioner condemns the behavior of these pension lawyers:

There are certain ignorant, unscrupulous, and useless persons, whose only object seems to be, first, to procure applications from soldiers, regardless of merit, to be filed through them, and then, while acting simply as transmitters of the papers, assiduously dun the claimant until the ten-dollar fee is secured, and thereafter practically abandon the case (United States Pension Bureau 1883, p. 16).

Pension attorneys received a fee of ten dollars for filing a pension claim, regardless of whether or not the claim had any merit; this could be quite lucrative. Attorneys would regularly advertise their services as pension agents in newspapers, which is one way that widows and veterans learned of their eligibility in the first place. Some of the larger, Washington, DC based pension attorneys owned newspapers. For example, George Lemon (one of the most frequently occurring pension lawyers in this article's sample) started the National Tribune in 1877, which devoted large amounts of space to describing pension eligibility requirements in the hopes of drumming up business (Blanck and Song 2002).

A challenge associated with using information about marital status from pension records is accuracy. Widows had a clear incentive to hide remarriages from the pension board, since disclosing this information would result in loss of pension. The incentive to fabricate marriages to veterans also existed. As the 1872 annual report of the pension commissioner remarks, "So long as pensions are to be granted upon evidence which (except record evidence) is purely ex parte, so long frauds will continue to exist" (United States Pension Bureau 1872, p. 13). The pension bureau was especially concerned about widows' claims: "The evidence to sustain a widow's or dependent's case is purely ex parte. As a result of this, a very considerable percentage of those cases are wrongfully established" (ibid). It is important to note that cohabiting couples were generally considered "married" for the purposes of pension eligibility, so the pension is unlikely to have encouraged women to substitute cohabitation for marriage. 
The marital (or cohabitation) status of widows drawing pensions was subject to oversight. If the pension authorities suspected a fraud, they would send a special examiner to the widow's place of residence to conduct an investigation. If found guilty of fraud, the widow lost her pension. Fraud was usually reported by either the postmaster who oversaw the delivery of pension vouchers and checks, or by members of the pensioner's community. There are a handful of examples in my sample of both sources reporting frauds. ${ }^{4}$ However, notwithstanding the pension bureau's concerns about fraud, there is little evidence that hidden remarriages were a frequent occurrence. Women receiving pensions regularly interacted with the pension board throughout their lives; yet, in only 20 out of the almost 800 cases analyzed in this study is there any indication of an investigation into pension fraud. Moreover, only a few of these cases resulted in the widow being stripped of her pension. Still, to address concerns about fraud, I check marital status using links to the federal censuses of 1870 and 1880 . Unless a large number of women were engaged in an elaborate fraud involving hiding second husbands from the census (which was totally administratively distinct from the pension bureau), hidden remarriages do not appear to pose a significant problem.

\section{DATA}

\section{Pension and Military Records}

Data used in this article come from three main sources, two of which are newly collected from primary sources. The first data source

\footnotetext{
${ }^{4}$ A letter of instruction to a special examiner in the case of Catherine Matthews describes allegations of remarriage by the postmaster of Malone, New York. The examiner is instructed to ascertain "whether the pensioner, by regular ceremony, by cohabitation, or by any other manner has performed such an act as will constitute marriage (re-marriage) under the laws of New York" (Widow's Certificate No. 6,916). Another example of fraud is the case of Maria van Buren, whose remarriage to Frank Stoffer is reported to the pension board by a close acquaintance. An excerpt from the examiner's report reads, "Stoffer had in his possession several letters, written in the same chirography, with the one hereto attached, none having a signature, all about equally dirty, but differing vastly in tone and purpose. The first a threatening message, demanding that she return to him by 7 o'clock and at least bid him farewell 'like a lady,' or he would have her in the penitentiary immediately. The next, breathing undying attachment of enormous dimensions, and asking her forgiveness for having 'told on her.' The third a sarcastic letter to Stoffer, and the fourth a letter of farewell and filled with threats of vengeance for her rejection of his 'ardent heart.' Mrs Van Buren acknowledged that she was living with Stoffer, and had done so 'off and on when she felt like it,' but denied that she had married him, denied that he is Van Buren, who is now, she remarked, if not in heaven, certainly not on earth; denied that she intended to run away and professed several times an unusually strong desire to be arrested. I was, of course, satisfied that the case was not one which I was authorized to further investigate without direct instruction" (Widow's Certificate No. 23,539). She was ultimately removed from the pension rolls because of remarriage, demonstrated by "cohabitation and recognition" (ibid).
} 
is the Union Army (UA) database created by the Center for Population Economics (CPE). ${ }^{5}$ I have chosen a random sample of approximately 800 women who were married to soldiers in the UA database. Useful for this study, this database provides information about soldiers' families, including when, where, and to whom they were married, as well as the birth dates and names of their children. I use this information to identify women that meet two important conditions. First, I restrict attention to women widowed by 1880 . This is because I expect such women to be most representative of the unmarried female population; they will be relatively young and thus more plausible marriage candidates. I choose 1880 as a cutoff because it facilitates the linking of my observations to the 1880 census. $^{6}$

The second restriction is that the widow had to apply for a pension within five years of her first husband's death. This restriction is intended to minimize sample selection bias due to limited data availability. Ideally, one would observe the widows of all soldiers in the UA database. However, because of the nature of this data source, the availability of spousal information depends on actions taken by subjects. For soldiers who died before 1880, all such information comes from dependents' pension applications, the vast majority of which are widows' applications. As such, it is extremely rare to observe a widow who never filed for a pension. ${ }^{7}$ Women who first applied for a pension, say, ten years after widowhood will be those who had not applied earlier and had not remarried during those ten years. This will be a highly selected sample of all widows who did not file for a pension before ten years had elapsed. Given that my sample is necessarily restricted to applicants, there is a certain amount of selection that is unavoidable; however, excluding late applicants should alleviate this problem.

The majority of the information I use in this article comes from data that I have collected from the Civil War pension files at the National Archives in Washington, DC. The CPE project focuses on soldiers' outcomes, so the UA database does not follow widows and children after

\footnotetext{
${ }^{5}$ These data were collected as part of the project Early Indicators of Later Work Levels, Disease, and Death, sponsored by the National Institutes of Health and the National Science Foundation (Federal grant number P01 AG10120; see Fogel 2000). See Appendix B (available online) for further details.

${ }^{6}$ I cannot link widows to the 1890 census, because these manuscripts were lost in a fire. Linking to the 1900 census is less useful, as most Civil War widows were well past the age at which they could reasonably expect to remarry by 1900 .

${ }^{7}$ Soldiers on the pension in 1898 were required to inform the pension bureau of the name of their spouse and children. Before 1898, it is possible to have spousal information about a soldier if his widow never filed a claim but his mother or children did; however, this is quite rare.
} 
the soldier died. After drawing my sample, I collect information about widows' pensions and marriage histories from their pension files. See Appendix B (available online) for details of the data collection process. Because these data are compiled from historical records and not from surveys designed to avoid selection bias, the source of every piece of information is important. With this in mind, I will explain in detail where my most important variables come from.

The pension information is largely straightforward to collect, as any action a widow took with respect to pensions is recorded in her correspondence with the pension bureau. The case files contain all materials in a widow's pension application, including her application form and supporting evidence. If the widow was granted a pension, her file will contain a pension brief and a pension certificate, indicating the amount of the pension, the effective start date, the date on which the pension was granted, the agency she was to be paid from, and the name of her attorney. ${ }^{8}$ If the widow did not receive a pension, it can be difficult to determine why. In later years, rejected claims contain a brief indicating the date of and reason for rejection; however, during the years immediately following the Civil War, information about rejection merely consists of a stamp somewhere in the file that reads "rejected." In such cases, it is impossible to determine the reason for or date of rejection. Similarly, if a widow abandoned her claim, I cannot be certain why or when.

Information about a widow's remarriage is slightly more complicated. Figure 1 illustrates all possible pension and marital outcomes for women in my sample. After applying for a pension, a widow may remarry or die before her claim is adjudicated. ${ }^{9}$ Otherwise, she will receive a decision from the pension board, which may be favorable or not. After receiving this decision, the widow may or may not remarry. The outcome of a pension application is always certain; however, in 20 percent of cases it is impossible to determine whether or not the widow ever remarried. ${ }^{10}$

A widow's remarriage is observable if her children filed a minors' pension claim or she applied to be restored to the pension rolls under the

\footnotetext{
${ }^{8}$ This information can be independently verified using the index to the pension files, which indicates the number attached to the widow's application and pension certificate. As these numbers were issued chronologically, the approximate date of application and issuance of the certificate can be inferred from these numbers.

${ }^{9}$ If a widow remarried with a pending claim, she was still entitled to be paid from the date of her widowhood to the date of her remarriage, provided she had applied for the pension before remarrying.

${ }^{10}$ After 1880, the pension bureau started including records of pensioners being dropped from the rolls for any reason. Women whose marital status is unknown are missing these records; thus, if they were on the pension, it is likely that they died, remarried, or stopped collecting their pensions some time before 1880 .
} 


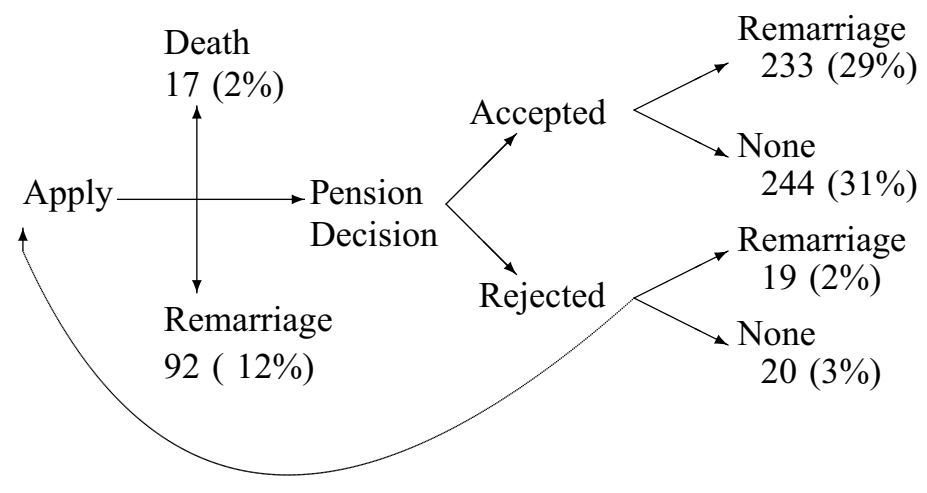

FIGURE 1

POSSIBLE OUTCOMES FOR WOMEN IN SAMPLE

Note: This figure illustrates all possible outcomes for widows in the sample, as well as the number (percentage in parentheses) of women in the sample that attain each outcome.

Source: Widows' Pension Database (see text for details).

act of 3 March 1901. A widow's failure to remarry is observable if her death date is known and there is no indication of remarriage. If she was receiving a pension when she died, her file will often contain a card indicating that she was dropped from the pension rolls due to death. If not, this information may come from minors' pension applications or other correspondence with the pension board. Marital status is not observable if the widow stopped communicating with the pension board some time before her death. The fact that knowledge of marital status is contingent on potentially endogenous actions taken with respect to pensions is of obvious concern and will be important to the sensitivity analysis I do later on.

\section{Selection of Union Army Pension Applicants}

Widows who filed for pensions may have been systematically different from widows who did not file, not to mention the population of unmarried women. In this section, I attempt to characterize selection into pension application. A good starting point is to establish the fraction of eligible widows married to men in the UA database that actually applied for pensions. A complication is that, among men who died before 1880, information on marital status almost always comes from widows' pension applications. Thus, if there is no widow's application attached to a soldier's file, it is impossible to know if this soldier was unmarried, or if his widow simply did not apply for a pension. Moreover, among men who died after the war ended, information about date of death often 
comes from widows' pension applications; so, a man with a missing death date may have died before 1880 and left a widow who simply failed to apply. Thus, to estimate an application rate among widows, it is necessary to make assumptions about the marital status and death date of observations with missing data. Table 1 contains such estimates. According to the most conservative estimate, 17 percent of widows of men who died before 1880 applied for pensions. A more reasonable estimate is that approximately half of widows of soldiers who died during the war applied for pensions. ${ }^{11}$ Thus, while many eligible women applied for pensions, a substantial number did not.

Given that not every widow applied for a pension, it is important to understand how applicants compare with non-applicants. Comparing women who did and did not apply for pensions is not straightforward, as women who did not apply for pensions do not appear in the UA database. However, the UA database contains links to the 1860 census, which allow me to observe some women who were married to soldiers but do not appear in the pension data. I impute marital status in the 1860 census based on position in the household, using a procedure similar to Ruggles et al. (2010). I then compare women married to recruits in 1860 who filed for pensions with women who did not. These results are presented in Table 2. Applicants are clearly somewhat selected. In particular, applicants were older on average than non-applicants. In addition, they were poorer and less likely to be married to literate men. As such, pensions appear to have been taken up by the most vulnerable women, who likely had the least favorable marriage prospects.

\section{Sample Characteristics}

Table 3 presents summary statistics from the pension file data (791 records in total). All women in this sample applied for a pension within five years of widowhood and had not remarried before doing so. The average age when widowed is 32; however, this ranges from 15 to 73 . There are 625 women for whom remarriage status is certain, meaning that I observe them either remarrying or dying while single. There is no

\footnotetext{
${ }^{11}$ This estimate assumes that the overall Union Army casualty rate prevailed in the UA database, so 16 percent of soldiers died. Given the sample size, this implies that 6,294 men died during the war. I assign a marriage probability to the men who died during the war based on age, state of residence, and occupational class (using predicted values from a regression of a marriage indicator on these variables using 1860 census data (Ruggles et al. 2010)): this indicates that approximately half of the war dead, or 3,311 men, were married. Thus, the presence of 1,755 applications from widows whose husbands died during the war implies an application rate of approximately one-half.
} 
TABLE 1

ESTIMATED FRACTION OF WIDOWS OBSERVED IN UNION ARMY DATABASE

\begin{tabular}{|c|c|c|c|c|c|c|c|c|c|c|}
\hline \multicolumn{11}{|c|}{ Panel A: Distribution of UA Database Observations by Veteran's Date of Death and Marital Status } \\
\hline \multirow[t]{3}{*}{ Category: } & \multirow[t]{3}{*}{ Total } & \multicolumn{6}{|c|}{ Died before $1880(\mathrm{~N}=7,953)$} & \multicolumn{3}{|c|}{ Date of Death Unknown $(\mathrm{N}=11,552)$} \\
\hline & & \multicolumn{3}{|c|}{ Total } & \multicolumn{3}{|c|}{ Dead During War $(\mathrm{N}=5,777)$} & \multirow[b]{2}{*}{ Married } & \multirow[b]{2}{*}{ Unmarried } & \multirow[b]{2}{*}{ Unknown } \\
\hline & & Married & Unmarried & Unknown & Married & Unmarried & Unknown & & & \\
\hline $\mathrm{N}:$ & 39,338 & 3,102 & 714 & 3,777 & 1,755 & 654 & 3,446 & 572 & 46 & 10,934 \\
\hline
\end{tabular}

Panel B: Estimates of the Fraction of Widows Observed in UA Database, under Different Assumptions about Missing Data

Assumption

Implied Fraction of Widows That Appear in the UA Data (Percent)

Reference group:

Died before $1880 \quad$ A1: Everyone with missing death date died before 1880, and everyone with missing marital status was married.

A2: Everyone with missing death date died before 1880 , and 63.4 percent of men who died before 1880 were married.

Died during war

A3: 16 percent casualty rate, and everyone with missing marital status was married.

A4: 16 percent casualty rate, and 52.6 percent of soldiers who died during the war were married.

Notes: This table provides estimates of the fraction Union Army widows who filed pension applications, using different assumptions about missing data. Marriage rates in A2 and A4 are imputed marriage rates for the full sample and the sample killed in the war, respectively. These are based on marriage probabilities imputed from a regression of marital status on age, state, and occupational class using the 18601 percent IPUMS sample. Calculation for A1: Total married and killed by $1880=3,102+3,777+572+10,934$; total applied $=3,102$. Calculation for A2: Total married and killed by $1880=0.643 *(7,953+11,552)$ $=12,541.7$; total applied $=3,102$. Calculation for A3: Total killed during war $=0.16 * 39338=6,294 ;$ total married and killed in war $=6,294-654=5640 ;$ total applied $=1,755$. Calculation for A4: Total killed during war $=6,294$ (from A3); total married and killed during war $=0.526 * 6294=3,311 ;$ total applied $=1,755$. Sources: Fogel (2000); Ruggles et al. (2010). 
TABLE 2

CHARACTERISTICS OF WIVES IDENTIFIED IN 1860 CENSUS LINKS SOLDIERS WHO DIED DURING THE WAR

\begin{tabular}{|c|c|c|c|c|}
\hline & \multicolumn{3}{|c|}{$t$ test for Equality of Means } & \multirow{2}{*}{$\begin{array}{c}\text { OLS Regression } \\
\text { Dependent Variable=1 } \\
\text { If Wife Observed } \\
\text { in Pension Data }\end{array}$} \\
\hline & $\begin{array}{l}\text { Mean: Wife } \\
\text { Observed in } \\
\text { Pension Data }\end{array}$ & $\begin{array}{l}\text { Mean: Wife } \\
\text { Not Observed in } \\
\text { Pension Data }\end{array}$ & $(1)-(2)$ & \\
\hline Wife's age & $\begin{array}{l}29.489 \\
(8.513)\end{array}$ & $\begin{array}{l}26.857 \\
(8.149)\end{array}$ & $2.632 * * *$ & $\begin{array}{c}-0.0096 * * * \\
(0.002)\end{array}$ \\
\hline Soldier's age & $\begin{array}{l}33.086 \\
(8.406)\end{array}$ & $\begin{array}{l}26.594 \\
(8.275)\end{array}$ & $6.492 * * *$ & $\begin{array}{c}0.0193 * * * \\
(0.002)\end{array}$ \\
\hline Wife literate & $\begin{array}{c}0.911 \\
(0.285)\end{array}$ & $\begin{array}{c}0.932 \\
(0.252)\end{array}$ & -0.020 & $\begin{array}{l}0.0064 \\
(0.048)\end{array}$ \\
\hline Soldier literate & $\begin{array}{c}0.915 \\
(0.279)\end{array}$ & $\begin{array}{c}0.967 \\
(0.171)\end{array}$ & $-0.056 * *$ & $\begin{array}{c}-0.0845^{*} \\
(0.050)\end{array}$ \\
\hline Wife immigrant & $\begin{array}{c}0.136 \\
(0.343)\end{array}$ & $\begin{array}{c}0.204 \\
(0.405)\end{array}$ & $-0.068 * *$ & $\begin{array}{c}-0.0880^{*} \\
(0.051)\end{array}$ \\
\hline Soldier immigrant & $\begin{array}{c}0.154 \\
(0.361)\end{array}$ & $\begin{array}{c}0.180 \\
(0.386)\end{array}$ & -0.028 & $\begin{array}{l}0.0107 \\
(0.048)\end{array}$ \\
\hline $\begin{array}{l}\text { HH head personal property } \\
\qquad(\$ 1,000)\end{array}$ & $\begin{array}{c}0.171 \\
(0.290)\end{array}$ & $\begin{array}{c}0.673 \\
(2.635)\end{array}$ & $-0.500 * * *$ & $\begin{array}{c}-0.0226 \\
(0.014)\end{array}$ \\
\hline $\begin{array}{l}\text { HH head real estate } \\
\qquad(\$ 1,000)\end{array}$ & $\begin{array}{c}0.490 \\
(1.052)\end{array}$ & $\begin{array}{c}1.473 \\
(4.334)\end{array}$ & $-0.984 * * *$ & $\begin{array}{c}-0.0205^{* * *} \\
(0.008)\end{array}$ \\
\hline Soldier farmer & $\begin{array}{c}0.305 \\
(0.461)\end{array}$ & $\begin{array}{c}0.308 \\
(0.464)\end{array}$ & -0.004 & \\
\hline Soldier professional or proprietor & $\begin{array}{c}0.034 \\
(0.180)\end{array}$ & $\begin{array}{c}0.068 \\
(0.252)\end{array}$ & $-0.036^{*}$ & $\begin{array}{c}-0.0518 \\
(0.067)\end{array}$ \\
\hline Solder skilled worker & $\begin{array}{c}0.209 \\
(0.407)\end{array}$ & $\begin{array}{c}0.075 \\
(0.265)\end{array}$ & $0.132 * * *$ & $\begin{array}{c}0.1106 * * * \\
(0.035)\end{array}$ \\
\hline Soldier laborer & $\begin{array}{c}0.215 \\
(0.411)\end{array}$ & $\begin{array}{c}0.263 \\
(0.442)\end{array}$ & -0.048 & $\begin{array}{l}0.0064 \\
(0.032)\end{array}$ \\
\hline Solder no occupation & $\begin{array}{c}0.007 \\
(0.085)\end{array}$ & $\begin{array}{c}0.008 \\
(0.087)\end{array}$ & -0.000 & $\begin{array}{l}0.1013 \\
(0.142)\end{array}$ \\
\hline Urban county & $\begin{array}{c}0.144 \\
(0.246)\end{array}$ & $\begin{array}{c}0.187 \\
(0.294)\end{array}$ & $-0.044 *$ & $\begin{array}{c}-0.1707 * * * \\
(0.057)\end{array}$ \\
\hline Northeast & $\begin{array}{c}0.413 \\
(0.493)\end{array}$ & $\begin{array}{c}0.353 \\
(0.480)\end{array}$ & 0.060 & $\begin{array}{l}0.0000 \\
(0.000)\end{array}$ \\
\hline Midwest & $\begin{array}{c}0.515 \\
(0.500)\end{array}$ & $\begin{array}{c}0.616 \\
(0.488)\end{array}$ & $-0.100^{* *}$ & $\begin{array}{c}-0.0506^{*} \\
(0.028)\end{array}$ \\
\hline South & $\begin{array}{c}0.066 \\
(0.248)\end{array}$ & $\begin{array}{c}0.030 \\
(0.171)\end{array}$ & 0.036 & $\begin{array}{l}0.0649 \\
(0.057)\end{array}$ \\
\hline $\mathrm{N}$ & 685 & 133 & & 801 \\
\hline
\end{tabular}

Notes: Sample of soldiers in UA database who died during the war, are linked to the 1860 census, and who appear to be married based on the composition of their household in 1860. Regression model includes a constant, and $\mathrm{R}^{2}=0.175$.

Source: Fogel (2000). 
TABLE 3

SUMMARY STATISTICS FROM PENSION FILE DATA

\begin{tabular}{|c|c|c|c|c|c|c|}
\hline Variable: & Mean & Median & SD & Min & Max & $\mathrm{N}$ \\
\hline \multicolumn{7}{|l|}{ Pension Variables } \\
\hline Applied within one year & 0.82 & 1.00 & 0.39 & 0.00 & 1.00 & 791 \\
\hline Time to first application & 0.68 & 0.29 & 0.97 & 0.01 & 5.77 & 791 \\
\hline General law claim accepted & 0.88 & 1.00 & 0.33 & 0.00 & 1.00 & 791 \\
\hline Processing time of accepted gen law claim & 2.25 & 0.93 & 4.19 & 0.07 & 50.50 & 692 \\
\hline \multicolumn{7}{|l|}{ Age/Marriage Variables } \\
\hline Age widowed & 32.12 & 31.00 & 9.40 & 15.00 & 73.00 & 769 \\
\hline Age at first marriage & 20.90 & 20.00 & 5.23 & 9.00 & 48.00 & 750 \\
\hline Age at remarriage & 32.23 & 31.00 & 7.50 & 18.00 & 65.00 & 332 \\
\hline Number of children (first marriage) & 2.56 & 2.00 & 2.15 & 0.00 & 13.00 & 791 \\
\hline Husband died during war years & 0.72 & 1.00 & 0.45 & 0.00 & 1.00 & 791 \\
\hline Remarried & 0.55 & 1.00 & 0.50 & 0.00 & 1.00 & 625 \\
\hline Remarried without pension & 0.17 & 0.00 & 0.37 & 0.00 & 1.00 & 672 \\
\hline \multicolumn{7}{|l|}{ Time to remarriage: } \\
\hline All & 4.34 & 3.38 & 3.54 & 0.23 & 26.04 & 340 \\
\hline Remarried with pending claim & 2.46 & 1.84 & 1.91 & 0.23 & 8.78 & 110 \\
\hline Remarried after pension & 5.24 & 4.35 & 3.79 & 0.86 & 26.04 & 230 \\
\hline Time to remarriage following pension & 3.74 & 2.61 & 3.68 & 0.00 & 25.46 & 225 \\
\hline \multicolumn{7}{|l|}{ Calendar Years } \\
\hline First marriage & 1854.38 & 1856.00 & 7.95 & 1822.00 & 1879.00 & 778 \\
\hline Widowhood & 1865.51 & 1864.00 & 4.49 & 1861.00 & 1879.00 & 790 \\
\hline Remarriage & 1868.84 & 1867.00 & 4.85 & 1863.00 & 1889.00 & 340 \\
\hline Pension application & 1866.21 & 1865.00 & 4.93 & 1862.00 & 1883.00 & 791 \\
\hline Pension certificate & 1869.15 & 1866.00 & 9.25 & 1862.00 & 1928.00 & 724 \\
\hline \multicolumn{7}{|l|}{ Region of Residence } \\
\hline New England & 0.11 & 0.00 & 0.32 & 0.00 & 1.00 & 778 \\
\hline Mid Atlantic & 0.31 & 0.00 & 0.46 & 0.00 & 1.00 & 778 \\
\hline East North Central & 0.42 & 0.00 & 0.49 & 0.00 & 1.00 & 778 \\
\hline West North Central & 0.09 & 0.00 & 0.29 & 0.00 & 1.00 & 778 \\
\hline South Atlantic & 0.02 & 0.00 & 0.15 & 0.00 & 1.00 & 778 \\
\hline East South Central & 0.03 & 0.00 & 0.18 & 0.00 & 1.00 & 778 \\
\hline West South Central & 0.00 & 0.00 & 0.04 & 0.00 & 1.00 & 778 \\
\hline Mountain & 0.00 & 0.00 & 0.00 & 0.00 & 0.00 & 778 \\
\hline Pacific & 0.00 & 0.00 & 0.04 & 0.00 & 1.00 & 778 \\
\hline
\end{tabular}

Notes: Sample includes women who were widowed before 1880 and who applied for a pension within five years of widowhood. Sample drawn from Union Army Database (Fogel. 2000). Data collected from Civil War pension files at the National Archives in Washington, DC.

Sources: Fogel (2000) and Widows' Pension Database (see text for details). 
evidence that the other 166 women either remarried or died. Of these 625 women, 55 percent remarried at some point in their lives, which implies that the true fraction of women who ever remarried is between 43 and 64 percent. Of the 672 women for whom this information is available, 16.5 percent remarried before receiving a pension. ${ }^{12}$ On average, a woman who remarried did so 4.3 years after her first husband's death. This average is much lower among women who remarried before getting a pension (2.5 years), which is unsurprising. It is, however, suggestive that the average time that elapsed between receiving a pension and remarriage is 3.7 years, which is much greater than 2.5 years. ${ }^{13}$

The average amount of time that elapsed between the soldier's death and his widow filing for a pension is eight months, and the median is less than four months. The probability of ever having a General Law claim accepted is 0.88 ; however, fewer than 80 percent of women were receiving a General Law pension within five years of applying. The average processing time for a pension is more than two years, although this is highly skewed: the median processing time is slightly less than one year. Most women in my sample were first married during the $1850 \mathrm{~s}$ and were widowed during the war. These women tend to come from the Mid Atlantic region (31 percent) or the East North Central region (42 percent). Very few come from the South or West.

\section{EMPIRICAL FRAMEWORK}

\section{Source of Variation in Pension Income: Theoretical Justification}

The major challenge associated with measuring the effect of widows' pensions on the timing of remarriage is locating an appropriate source of variation in pension income to exploit. Because pension amounts are standardized, there is no variation in pension income among pensioners. Moreover, it is not straightforward to compare women who had pensions with those who did not, as I do not observe women who never make pension applications. As such, there are two usable sources of variation in pension income: the pension board's decision and the timing of this decision.

\footnotetext{
${ }^{12}$ Even if I do not know whether or not a widow ever remarried, I may know that she did not remarry with a pending claim if she communicated with the pension board subsequent to her claim being granted.

${ }^{13}$ I have tested the sensitivity of the main results to omitting some of the clear outliers in processing time and age at first marriage.
} 
The pension board's decision is not an ideal source of variation for a few reasons. First, this variable is only defined for women who complete their claims. Recall from Figure 1 that at least 12 percent of my sample remarried while their claims were pending. A simple comparison between women with accepted and rejected claims will discard this potentially valuable information. Another issue is that rejections take significantly longer to process than acceptances. It takes approximately five years longer to reach the "rejected" node in Figure 1 than the "accepted" node. Thus, my sample of rejected widows ought to look very different from the universe of potentially rejected widows, as many of these are likely to have remarried before the board's decision was rendered. A final technical issue has to do with accuracy: it is often unclear when or why a claim was rejected.

Because of these issues, I use variation in the timing of the pension board's decision, rather than the outcome, to estimate the effect of pensions on the timing of remarriage. Specifically, I look for a treatment effect of having a pension claim granted, or of transitioning from having a pending claim to an accepted claim. So long as there is uncertainty about if and when a pension claim will be approved - and discounting of future income-having a claim accepted will represent a real positive utility shock. As described earlier, there are a number of reasons for a claim to experience a processing delay, some predictable and some not. Certainly, a claim of dubious merit took longer to process. However, a straightforward claim, for example, could be delayed if it was neglected by a pension lawyer, or if evidence was delayed or lost in the mail, or if the War Department had difficulty locating a veteran's military record. ${ }^{14}$ In Appendix A (available online), I develop a simple search model of marriage and pensions, in which I show that, in the presence of this type of uncertainty, widows with accepted claims will have higher reservation match qualities and will spend less effort searching for mates than

\footnotetext{
${ }^{14}$ In Figure A1 (available online), I plot $R^{2}$ from a regression of pension processing time on observable characteristics, including age, husband's date of death, time to first pension application, number of children, attorney indicators, characteristics of the first husband, county characteristics, and region indicators. I do this for progressively larger samples, consisting of pensions processed within one year to pensions processed within 25 years. Covariates can explain up to 30 percent of the variation in processing times, leaving 70 percent of this variation unexplained. It is notable that the fraction of variation explained by covariates falls as the sample is confined to pensions processed within a shorter time frame. For instance, covariates only explain about 12 percent of the variation in processing times among claims processed within five years. This indicates that covariates do a good job of explaining the difference between, say, a processing time of one year and a processing time of ten years; however, much of the short-run variation in processing times is random. As I will show, much of the "action" in pension decisions and remarriages occurs within the first five years.
} 
widows with pending claims. As such, the rate of remarriage should shift discontinuously downward at the moment a pension is granted. As Raj Chetty (2008) discusses (in the context of the labor market), this shift in the rate of remarriage likely embeds two effects: a "moral hazard" effect, in which the marginal incentive to search for a mate is reduced by the increased income while single, and a "liquidity" effect, in which liquidity constrained women expend great effort and accept suboptimal matches out of immediate financial need. Because the probability of having a claim rejected is quite low (approximately 12 percent), the difference between the lifetime income of a woman with an approved claim and a woman with a pending claim is quite low. As such, it is likely that any discernible changes in behavior that occur upon the approval of a pension claim are driven by liquidity constraints on the part of the widow.

\section{Empirical Approach: Details}

To evaluate the effect of the pension on the rate of remarriage, I estimate a proportional hazards model of both pensions and marriage, allowing the rate of remarriage to shift at the moment a pension is granted. Variation in processing times allows me to observe women with and without pensions at every point in time, which allows me to estimate a hazard rate of remarriage that differs by pension status. Some of this variation is plausibly exogenous. For example, idiosyncrasies in the postal service, clerical errors, or unexpectedly capricious behavior on the part of pension attorneys certainly affected processing times in a random fashion. However, a portion of the variation in processing times is likely endogenous to marital outcomes. For example, women with poor marriage prospects may have been more invested in getting a pension because they knew their alternatives were poor. So, those who got pensions quickly may have tended to remarry slowly because of poor marriage prospects, not because of a causal effect of the pension.

Another concern is that processing times are highly correlated with the quality of a pension claim: rejections take significantly longer to process than acceptances. This may introduce bias through the decision to apply. Applying for a pension is costly: a widow will choose to incur this cost if the benefit is great enough. The expected benefit from applying is lower for a widow with an ambiguous claim, as the probability of ever receiving a pension is low. Thus, women who apply with ambiguous claims may be systematically different from women who apply with straightforward claims. In particular, they may have worse alternatives, either financially or in the marriage market. The direction of this bias on the timing of 
remarriage is unclear: women with poor alternatives might receive fewer proposals per unit of search effort; however, they might also be less selective.

To address these concerns, I use a method developed by Jaap H. Abbring and Gerard J. Van den Berg (2003a, 2005). This is a novel approach to identifying treatment effects in the presence of an endogenous treatment when both the treatment and outcome are duration variables. The approach involves jointly estimating the hazard rates of pensions and remarriage, allowing for correlation between the unobserved heterogeneity in these two risks. The hazard rate at time $t$ refers to the probability of realizing an outcome (pension or marriage) at $t$, conditional on not having realized it earlier. The hazard rate of pension receipt is given by

$$
\theta_{p}\left(t \mid X, v_{p}\right)=\lambda_{p}(t) \exp \left(X \beta_{p}+v_{p}\right),
$$

and the hazard rate of marriage is given by

$$
\theta_{m}\left(t \mid X, v_{m}, t_{p}\right)=\left\{\begin{array}{cc}
\lambda_{m}(t) \exp \left(X \beta_{m}+v_{m}\right), & t \leq t_{p} \\
\lambda_{m}(t) \exp \left(X \beta_{m}+\delta+v_{m}\right), & t>t_{p}
\end{array} .\right.
$$

For each $i \in\{p, m\}, \lambda_{i}$ is the baseline hazard function, which characterizes duration dependence, and $X$ is a matrix of explanatory variables that may shift the hazard rate. The term $t_{p}$ represents the time at which a pension is granted, and $v_{i}$ represents unobserved heterogeneity.

The threat to identification is that $v_{m}$ and $v_{p}$ may be correlated. In particular, if $v_{m}$ and $v_{p}$ are negatively correlated, the estimate of $\delta$ may be negative even if the true $\delta$ is zero. Correlated unobserved heterogeneity generates bias in a similar fashion to omitted observable controls. If women who get pensions quickly tend to have large values of $v_{p}$, they will also tend to have small values of $v_{m}$, which means they are likely to take longer to remarry even if the pension itself has no causal effect.

Abbring and Van den Berg (2003a, 2003b) show that this model is identified even if $v_{m}$ and $v_{p}$ are correlated. Moreover, it is identified without exclusion restrictions or assumptions about the functional form of the baseline hazard or the joint distribution of unobserved heterogeneity; the necessary assumption is proportional hazards. In a simple proportional hazards setting, the distribution of unobserved heterogeneity is identified from variation in observables. To see this, consider the rate of pension receipt. Suppose one woman has a very good pension attorney (high $X \beta_{p}$ ), and a second woman with otherwise identical observables has a 
poor pension attorney (low $X \beta_{p}$ ). Now, suppose these women both take a long time to receive a pension (large $t_{p}$ ). We can infer from this that the first woman is more likely to have an ambiguous pension claim (low $v_{p}$ ) than the second woman: because the first woman has a good lawyer, the ambiguity of her claim must be what causes it to be processed slowly. In general, the distribution of $v_{p}$, conditional on $t$, depends on observables, which allows its distribution to be pinned down.

How does this help to identify correlated unobserved heterogeneity in the rates of remarriage and pension receipt? Using the same example, suppose that the quality of pension attorney has no direct effect on the rate of remarriage, so women with good and bad pension attorneys have the same $X \beta_{m}{ }^{15}$ This means that we should not expect to see a systematic relationship between marital outcomes and lawyer quality. However, recall that, conditional on $t$, the distribution of $v_{p}$ is not independent of lawyer quality. So, if $v_{m}$ and $v_{p}$ are correlated, the distribution of $v_{m}$ will also depend on pension lawyer quality.

For example, say $v_{m}$ and $v_{p}$ are negatively correlated, and recall that, fixing $t, \mathrm{E}\left(v_{p}\right)$ is higher for women with bad lawyers than it is for women with good lawyers. This means that, among women observed at time $t$, those with good lawyers will tend to remarry fastest, because these women tend to have higher $v_{m}$. Similarly, if $v_{m}$ and $v_{p}$ are positively correlated, women with bad lawyers will tend to remarry more quickly. In other words, different joint distributions of $v_{m}$ and $v_{p}$ will be observationally distinct. Once the correlation between $v_{m}$ and $v_{p}$ has been corrected

\footnotetext{
${ }^{15}$ This example is used for clarity and does not imply the necessity of an exclusion restriction for identification. In general, as long as $X \beta_{m} \neq X \beta_{p}$ and there is sufficient variation in the data, there exists some $X, X^{\prime}$ such that $X \beta_{m}=X^{\prime} \beta_{m}^{m}$ but $X \beta_{p} \neq X^{\prime} \beta_{p}$ (Abbring and van den Berg 2003a, $2003 \mathrm{~b}, 2005)$. This is all that is required. Also notice that the values of $\beta_{m}, \beta_{p}$ are identified using the "early" part of the sample, when $v_{m}$ and $v_{p}$ are independent of observables. This dependency arises "later" in the sample, due to selective attrition. Note that identification relies heavily on the proportional hazards assumption. In Table A2 (available online), I test the assumption that the variables included in $X$ affect the hazard rates of remarriage and pension receipt proportionally. Specifically, I estimate Cox proportional hazards models of remarriage and pension receipt, and I report $p$ values from chi-squared tests of the hypothesis that covariates affect the rate of remarriage or pension receipt in the same way at all times (Shoenfeld 1980; Grambsch and Therneau 1994). In almost all cases, I fail to reject the hypothesis that hazards are proportional. One covariate- the time to elapse between a widow's husband's death and her initial pension application-appears not to affect either hazard rate proportionally. However, the results are not at all sensitive to the inclusion or exclusion of this covariate (Table A3). Moreover, the results are not sensitive to restricting the sample to "short" application times, and this apparent non-proportionality vanishes under this sample restriction (shown in Table 6). The covariates that have the greatest bearing on my results are the widow's age and her husband's year of death (Table A3). These appear to affect the hazard rates of remarriage proportionally; I also plot Kaplan-Meier survival estimates separately by age and year-of-widowhood cohorts in Figure A2. Nothing suggests an obvious departure from proportional hazards.
} 
for, the remaining difference between the marriage rate before and after a pension is granted can be interpreted as a causal effect of the pension. ${ }^{16}$

I estimate this model by maximum likelihood, using the EM algorithm (Heckman and Singer 1984). I use a piecewise constant function for the baseline hazard function, and I use a discrete distribution with two mass points for the distribution of the unobserved heterogeneity terms. This follows Abbring and Van den Berg (2005), and is generally considered the least restrictive set of parametric assumptions for this type of model. See Appendix C (available online) for further estimation details.

\section{THE IMPACT OF RECEIVING A PENSION ON THE RATE OF REMARRIAGE}

Before presenting estimates of the model described in the previous section, it is useful to get a sense of what the hazard rates of remarriage and pension receipt look like. Figure 2 plots the empirical hazard rate of both pension decisions and remarriage, estimated non-parametrically using a kernel method. ${ }^{17}$ Panel A illustrates the rate of remarriage measured before and after a pension is granted; panel B illustrates the hazard rate of pension decisions. Time is measured in years since widowhood; however, individuals do not enter the sample until they apply for a pension. Notice that, for the first four years, the rate of remarriage for women who have not yet received a pension lies uniformly above that of women who have pensions. After four years, the two lines are close to one another, with the rate of remarriage slightly lower for women with pending claims. This may indicate that the pension only lowers the rate of remarriage in the short run; however, it may also reflect differences in the characteristics of pensioned and unpensioned women in later years. It is important to note that these empirical hazard rates are calculated without controlling for observable or unobservable characteristics.

Table 4 contains parameter estimates for the model described earlier, with the estimated effect of covariates on the rate of pension receipt listed next to their estimated effect on the rate of remarriage. In column (1), I estimate the model with no covariates or correction for correlated unobserved heterogeneity. In this specification, the estimated effect of the pension is barely negative and not significantly different

\footnotetext{
${ }^{16}$ A number of other applied articles have used the Abbring and Van den Berg (2003a) method. For instance, Gans, Hsu, and Stern (2008) use variation in the timing of patent grants to identify the effect of uncertain intellectual property rights on innovation. Munch, Rosholm, and Svarer (2008) use the timing of transitions in home ownership status to identify the effect of home ownership on job-to-job mobility. Abbring and Van den Berg (2005) use the timing of unemployment benefit sanctions to identify the effect of unemployment insurance benefits on the rate of re-employment.

${ }^{17}$ This is done using the STS package in STATA.
} 

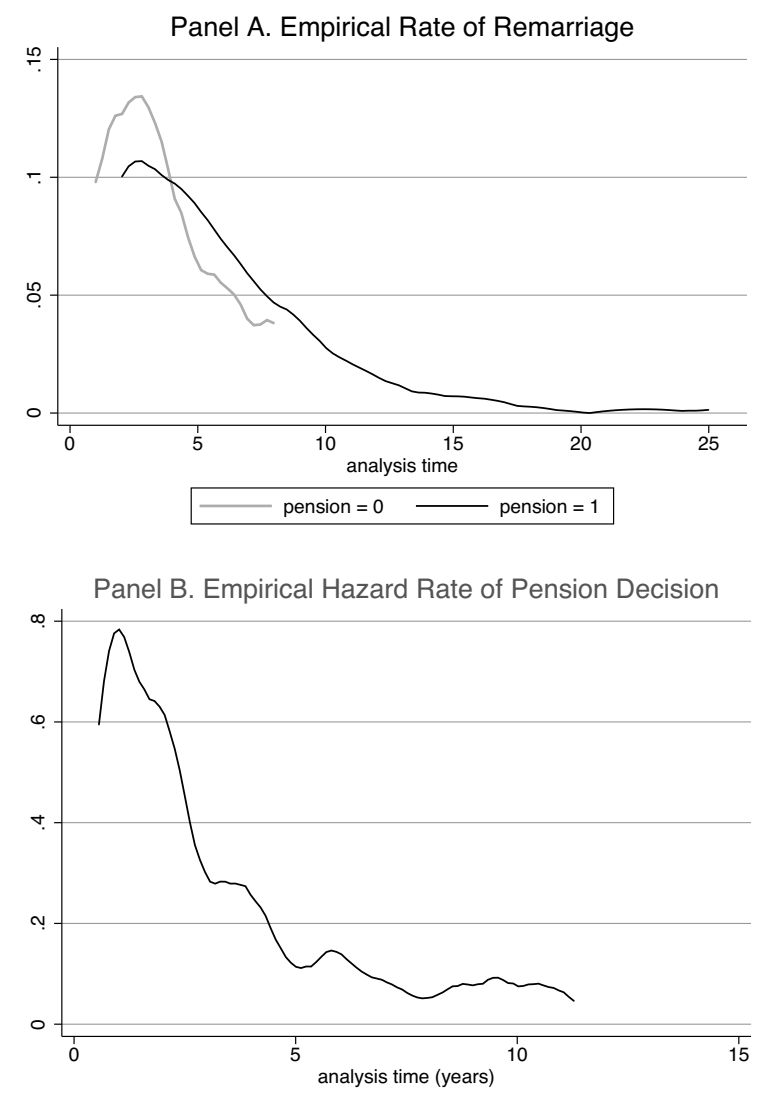

FIGURE 2

EMPIRICAL HAZARD RATE OF REMARRIAGE AND PENSION DECISIONS

Note: Panel A plots the nonparametric empirical hazard rate of remarriage, separated by pension status, and estimated using a kernel method (STS package in STATA). Panel B does the same for the hazard rate of pension receipt.

Source: Widows' Pension Database (see text for details).

from zero. In column (2), I add covariates to the hazard rate of both risks, which significantly increases the magnitude of the estimate, to $-0.271(0.155)$, which is significant at the 10 percent level. This suggests that selection on observables biases this effect toward zero. Sequentially introducing control variables indicates that the influential controls are age and year of widowhood. The reason is intuitive. Age at widowhood and year of widowhood are not independent: women widowed at a later date also tend to be older. Age at widowhood tends to lower the rate of remarriage. At the same time, year of widowhood tends to lower the rate of pension receipt, as it becomes more difficult for a widow to prove that her husband died as a direct result of his military service if he died years after the war ended. As such, excluding these two variables biases the estimated effect of the pension toward zero. 
TABLE 4

DETERMINANTS OF THE HAZARD RATE OF REMARRIAGE AND PENSION RECEIPT

\begin{tabular}{|c|c|c|c|c|c|c|}
\hline \multirow[b]{2}{*}{ Outcome: } & \multicolumn{2}{|c|}{ (1) } & \multicolumn{2}{|c|}{ (2) } & \multicolumn{2}{|c|}{ (3) } \\
\hline & Remarriage & Pension & Remarriage & Pension & Remarriage & Pension \\
\hline \multirow[t]{2}{*}{ Effect of pension } & -0.036 & & $-0.269 *$ & & $-0.283^{*}$ & \\
\hline & $(0.130)$ & & $(0.154)$ & & $(0.159)$ & \\
\hline \multirow[t]{2}{*}{ Age at widowhood } & & & $-0.094 * * *$ & 0.004 & $-0.096 * * *$ & 0.004 \\
\hline & & & $(0.012)$ & $(0.008)$ & $(0.014)$ & $(0.009)$ \\
\hline \multirow[t]{2}{*}{ Number of Children } & & & -0.067 & -0.021 & -0.072 & -0.021 \\
\hline & & & $(0.047)$ & $(0.029)$ & $(0.052)$ & $(0.030)$ \\
\hline \multirow[t]{2}{*}{ Potential minor pension at widowhood } & & & $-0.056 * * *$ & $-0.071 * * *$ & $-0.057 * * *$ & $-0.071 * * *$ \\
\hline & & & $(0.020)$ & $(0.013)$ & $(0.021)$ & $(0.013)$ \\
\hline \multirow[t]{2}{*}{ Year of widowhood } & & & 0.048 & $-0.164 * *$ & 0.034 & $-0.164 * *$ \\
\hline & & & $(0.086)$ & $(0.076)$ & $(0.094)$ & $(0.076)$ \\
\hline \multirow[t]{2}{*}{ Time to pension application } & & & 0.056 & 0.136 & 0.061 & 0.136 \\
\hline & & & $(0.130)$ & $(0.096)$ & $(0.141)$ & $(0.096)$ \\
\hline \multirow[t]{2}{*}{ No pension attorney } & & & 0.228 & 0.269 & 0.237 & 0.269 \\
\hline & & & $(0.205)$ & $(0.164)$ & $(0.214)$ & $(0.164)$ \\
\hline \multirow[t]{2}{*}{ Washington pension attorney } & & & 0.142 & -0.084 & 0.145 & -0.084 \\
\hline & & & $(0.162)$ & $(0.132)$ & $(0.169)$ & $(0.133)$ \\
\hline \multirow[t]{2}{*}{ First husband: age at death } & & & 0.017 & -0.009 & 0.018 & -0.009 \\
\hline & & & $(0.012)$ & $(0.009)$ & $(0.013)$ & $(0.010)$ \\
\hline \multirow[t]{2}{*}{ First husband: log occupational wage } & & & 0.193 & -0.244 & 0.220 & -0.244 \\
\hline & & & $(0.353)$ & $(0.238)$ & $(0.427)$ & $(0.243)$ \\
\hline
\end{tabular}


First husband: height (feet)

County male-to-female ratio

County percent urban

County population density

Mid Atlantic

East North Central

West North Central

South

$\lambda$ for years:

$[1,2)$

$[2,3)$

$\begin{array}{cccc}-0.439 & -0.214 & -0.448 & -0.215 \\ (0.281) & (0.219) & (0.300) & (0.223) \\ 2.428^{* * *} & -0.254 & 2.539 * * * & -0.254 \\ (0.875) & (1.004) & (0.903) & (1.077) \\ 0.396 & 0.273 & 0.401 & 0.273 \\ (0.293) & (0.225) & (0.304) & (0.227) \\ -0.035^{*} & -0.018^{* *} & -0.036^{*} & -0.018^{*} \\ (0.020) & (0.009) & (0.021) & (0.009) \\ 0.202 & -0.674^{* * *} & 0.211 & -0.674^{* * *} \\ (0.217) & (0.165) & (0.227) & (0.166) \\ 0.092 & -0.553^{* * *} & 0.089 & -0.553^{* * *} \\ (0.221) & (0.178) & (0.230) & (0.182) \\ 0.442 & -0.482^{* *} & 0.445 & -0.482^{* *} \\ (0.289) & (0.239) & (0.298) & (0.246) \\ -0.555 & -0.697 * * * & -0.580 & -0.697 * * * \\ (0.353) & (0.248) & (0.372) & (0.249) \\ & & & \\ 1.833^{* * *} & 1.191 * * * & 1.965^{* * *} & 1.191 * * * \\ (0.456) & (0.137) & (0.534) & (0.137) \\ 2.129 * * * & 1.026^{* * *} & 2.386^{* * *} & 1.026^{* * *} \\ (0.553) & (0.158) & (0.764) & (0.159)\end{array}$


TABLE 4 (CONTINUED)

DETERMINANTS OF THE HAZARD RATE OF REMARRIAGE AND PENSION RECEIPT

\begin{tabular}{|c|c|c|c|c|c|c|}
\hline \multirow[b]{2}{*}{ Outcome: } & \multicolumn{2}{|c|}{ (1) } & \multicolumn{2}{|c|}{ (2) } & \multicolumn{2}{|c|}{ (3) } \\
\hline & Remarriage & Pension & Remarriage & Pension & Remarriage & Pension \\
\hline \multirow[t]{2}{*}{3,4} & $1.423 * * *$ & $0.465 * * *$ & $2.143 * * *$ & $0.741 * * *$ & $2.461 * * *$ & $0.741 * * *$ \\
\hline & $(0.350)$ & $(0.090)$ & $(0.587)$ & $(0.160)$ & $(0.880)$ & $(0.160)$ \\
\hline \multirow[t]{2}{*}{4,5} & $1.127 * * *$ & $0.292 * * *$ & $1.872 * * *$ & $0.590 * * *$ & $2.181^{* *}$ & $0.590 * * *$ \\
\hline & $(0.296)$ & $(0.076)$ & $(0.551)$ & $(0.170)$ & $(0.847)$ & $(0.170)$ \\
\hline \multirow[t]{2}{*}{5,6} & $1.160 * * *$ & $0.167 * * *$ & $2.052 * * *$ & $0.301 * *$ & $2.413 * *$ & $0.301 * *$ \\
\hline & $(0.309)$ & $(0.060)$ & $(0.623)$ & $(0.129)$ & $(0.973)$ & $(0.130)$ \\
\hline \multirow[t]{2}{*}{6,7} & $0.668 * * *$ & $0.251 * * *$ & $1.329 * * *$ & $0.517 * * *$ & $1.572^{* *}$ & $0.517 * * *$ \\
\hline & $(0.210)$ & $(0.081)$ & $(0.462)$ & $(0.196)$ & $(0.697)$ & $(0.196)$ \\
\hline \multirow[t]{2}{*}{7,8} & $0.626 * * *$ & $0.117^{* *}$ & $1.188 * * *$ & $0.328^{*}$ & $1.409^{* *}$ & $0.327 *$ \\
\hline & $(0.205)$ & $(0.059)$ & $(0.437)$ & $(0.170)$ & $(0.651)$ & $(0.170)$ \\
\hline \multirow[t]{2}{*}{$8, \infty$} & $0.078 * * *$ & $0.249 * * *$ & $0.169 * * *$ & $0.601 * * *$ & $0.201 * *$ & $0.601 * * *$ \\
\hline & $(0.020)$ & $(0.041)$ & $(0.050)$ & $(0.131)$ & $(0.084)$ & $(0.132)$ \\
\hline \multirow[t]{2}{*}{$v_{\text {low }}($ constant in columns 1-2) } & $-2.543^{* * *}$ & $-0.473^{* * *}$ & -1.729 & 3.316 & -2.066 & 3.317 \\
\hline & $(0.184)$ & $(0.071)$ & $(2.785)$ & $(2.181)$ & $(3.464)$ & $(2.281)$ \\
\hline \multirow[t]{2}{*}{$v_{\text {high }}$} & & & & & \multicolumn{2}{|c|}{-0.347} \\
\hline & & & & & \multicolumn{2}{|c|}{$(3.289)$} \\
\hline \multirow[t]{2}{*}{$\pi_{1}$} & & & & & \multicolumn{2}{|c|}{$0.968 * * *$} \\
\hline & & & & & \multicolumn{2}{|c|}{$(0.057)$} \\
\hline \multirow[t]{2}{*}{$\pi_{2}$} & & & & & \multicolumn{2}{|c|}{0.032} \\
\hline & & & & & \multicolumn{2}{|c|}{$(0.045)$} \\
\hline
\end{tabular}


Notes: Hazard coefficients are reported. Sample: women widowed before 1880 who applied for a pension within five years of husband's death. Column (3) includes a correction for correlated unobserved heterogeneity, and does not include a constant as this is not identified separately from one of the mass points in the distribution of the unobserved heterogeneity terms; columns (1) and (2) make no such adjustment, and include a constant. Age at widowhood and all widows' pension variables (including county of residence) are taken from the pension file data collected by the author. First husband characteristics come from the UA database and are based on enlistment variables; occupational wages measured using 1900 occupational wage distribution assigned to 1950 occupational codes, with an imputed wage for farmers (Preston and Haines 1991; Abramitzky, Boustan, and Eriksson 2012; Olivetti and Paserman 2015; Salisbury 2014). Countylevel variables are taken at the time of pension application; they are a weighted average of these variables at the decadal censuses preceding and following the date of pension application (Haines and ICPSR 2010). On the time interval $[0,1)$, the hazard rate of both risks is normalized to one (this is necessary because I include a constant in the model). The variables $\mathrm{v}_{\text {low }}$ and $\mathrm{v}_{\text {high }}$ are the two mass points in the distributions of $\mathrm{v}_{\mathrm{m}}$ and $\mathrm{v}_{\mathrm{p}}$. Note that both mass points in the distribution of $\mathrm{v}$ converge to the same value. The variables $\pi 1-\pi 2$ are the estimated probability of each unobserved heterogeneity event.

Sources: Fogel (2000) and Widows' Pension Database (see text for details). 
In column (3), I introduce the possibility of correlated unobserved heterogeneity in the rates of pension receipt and remarriage. At -0.283 (0.159), the estimated effect of the pension changes little from the previous specification, suggesting that much of the selection is on observables. The estimate from the full model can be interpreted to mean that receiving a pension lowered the hazard rate of remarriage by 25 percent. ${ }^{18}$ This estimate implies that, for a woman with median characteristics, immediately granting her a pension would raise her median time to remarriage from 5.7 to 9.2 years, an increase of 3.5 years. ${ }^{19}$ This timing increase is consistent with the summary statistics from Table 1, although the implied medians are substantially higher than they are in this table, as they should be. These summary statistics are calculated using women who actually remarry. The medians implied by the model estimates incorporate information from women who never remarry, which will tend to raise them substantially.

The unobserved heterogeneity terms are imprecisely estimated. In fact, the two mass points in the distribution of $v_{p}$ converge to indistinguishably similar values, which means that it is impossible to calculate standard errors for the probability of observing each of these values. Because of this, I have restricted both mass points to take on the same value, which follows Abbring and Van den Berg (2005). This likely indicates that unobserved heterogeneity in the rate of pension receipt is well controlled for by covariates and the duration dependence function, leaving little systematic unobserved heterogeneity.

In Table 5, I estimate heterogeneous effects of receiving a pension on the rate of remarriage by interacting the effect of the pension with different observable variables: age, number of children, county male-tofemale ratio, population density, a measure of the widow's wealth, and region of residence. Continuous variables are demeaned, so the estimated $\delta$ should be interpreted as the effect at the mean value of the interaction variable. The widow's wealth is not taken from the pension file data, as the pension bureau did not ask about a pension applicant's means. However, the Union Army database links soldiers to the 1860 census,

\footnotetext{
${ }^{18}$ This comes from the fact that $\frac{\theta^{\text {PEN }}}{\theta^{\text {NOPEN }}}=e^{-0.283}=0.75$, so $\frac{\theta^{\text {PEN }}-\theta^{\text {NOPEN }}}{\theta^{\text {NOPEN }}}=-0.25$.

${ }^{19}$ The hazard rate of remarriage implies a different survival function $S(t)$ —or probability of not having remarried by time $t$ - for women with and without pensions. Formal expressions for $S(t)$ are given in Appendix C (available online). To calculate the effect of receiving a pension on the median time to remarriage, I calculate the median time to remarriage for women with identical characteristics with and without a pension and take the difference. To calculate the median time to remarriage, I solve the following expression numerically for $t_{\text {med }}: 0.5=S\left(t_{\text {med }} \mid X, v_{m}\right)$, where the function $S($.) differs by pension status. For $X$, I use median characteristics and mean regions; I integrate over $v_{m}$ and $v_{p}$ using estimates from the model.
} 
TABLE 5

EFFECT OF PENSION ON MARRIAGE RATE: INTERACTIONS WITH COVARIATES

\begin{tabular}{|c|c|c|c|c|c|}
\hline Interaction Variable: & Age & Number of Children & Male to Female Ratio & Population Density & Soldier 1860 Wealth \\
\hline \multirow[t]{2}{*}{ Pension } & $-0.545 * * *$ & $-0.299 *$ & $-0.273 *$ & $-0.282 *$ & -0.239 \\
\hline & $(0.170)$ & $(0.155)$ & $(0.158)$ & $(0.158)$ & $(0.201)$ \\
\hline Pension $\mathrm{X}$ variable & $(0.017)$ & $(0.067)$ & $(1.621)$ & $(0.035)$ & $(0.089)$ \\
\hline Log likelihood & -1847.944 & -1851.558 & -1854.555 & -1854.508 & -1247.970 \\
\hline Interaction Variable: & New England & Mid Atlantic & East North Central & West North Central & South \\
\hline \multirow[t]{2}{*}{ Pension } & -0.231 & $-0.373 * *$ & -0.077 & $-0.291^{*}$ & $-0.330 * *$ \\
\hline & $(0.157)$ & $(0.173)$ & $(0.201)$ & $(0.160)$ & $(0.156)$ \\
\hline \multirow[t]{2}{*}{ Pension $\mathrm{X}$ variable } & -0.662 & 0.355 & -0.385 & 0.205 & $1.423 *$ \\
\hline & $(0.440)$ & $(0.279)$ & $(0.248)$ & $(0.404)$ & $(0.788)$ \\
\hline Observations & 688 & 688 & 688 & 688 & 688 \\
\hline
\end{tabular}

Notes: Table reports results from simple model with no correction for unobserved heterogeneity; results with this correction look very similar. All specifications include the full set of controls from Table 4; see notes to this table for explanation. Soldier's 1860 wealth is derived from links to the 1860 census in the CPE database. Only observations that have been successfully linked to this census are included in this specification.

Sources: Fogel (2000) and Widows' Pension Database (see text for details). 
and these links contain information about the soldier's wealth (or the wealth of the head of the soldier's household in 1860). I use this as a rough measure of the widow's wealth after the soldier dies. Only twothirds of my sample has been linked to the 1860 census, so I do not use this variable in the baseline specification.

There is some evidence of heterogeneity in the effect of the pension across regions, although there is no evidence of heterogeneity by geographic characteristics related to marriage market conditions, that is, sex ratios or population density. The interaction with the first husband's wealth is insignificant, but the point estimate is positive, which suggests that the rate of remarriage among wealthier widows may have been less influenced by pension receipt. This may reflect the fact that the pension represented a smaller shock to the utility of wealthier women, or that wealthy women were less bound by liquidity constraints. The strongest result comes from interacting the effect of the pension with the widow's age and number of children. Receiving a pension has a significantly larger effect on older women and women with more children.

The results in the first column of Table 5 indicate that, for women widowed at age 32 (the median age at widowhood), receiving a pension causes the hazard rate of remarriage to fall by $0.545(0.170)$, and that this effect grows in magnitude by $0.061(0.017)$ with every additional year of age. The difference in the effect by age is quite striking: for a 25 -yearold woman, receiving a pension causes the median time to remarriage to increase very little, from 4.1 to 4.6 years. However, for a 35 -yearold woman, receiving a pension increases the median time to remarriage from 7.6 to 71.3 years. ${ }^{20}$ This can be interpreted to mean that the median 35 year old woman who receives a pension is predicted not to remarry: receiving a pension lowers the probability that a 35 woman has remarried within ten years of widowhood from 0.52 to 0.30 .

\section{SENSITIVITY ANALYSIS}

A concern is that the results may be sensitive to the source of information on remarriage. Recall that knowledge of a widow's remarriage is contingent on her communicating in some way with the pension board. Specifically, I observe a widow's remarriage if her children file a minors' pension claim, or if she files a new claim under the act of 3 March 1901. If the source of information is distributed differently among women who remarry before and after obtaining a pension, and if the source of this information is correlated with marital outcomes, this might bias

\footnotetext{
${ }^{20}$ See footnote 19 for an explanation of this calculation.
} 
my results. For example, minors' pension applications are the source of evidence of remarriage in 71 percent of cases that occur before a pension is granted and 85 percent of cases that occur after a pension is granted. This means that my sample of women who remarry before receiving a pension must be disproportionately composed of childless women who lived to 1901 . These women may be younger and healthier by construction, and thus better marriage prospects.

I use two alternative sample restrictions to address this concern. First, I restrict the sample to women who have children under the age of 16 when they are widowed. So, these women's remarriages are potentially observable through a child's pension application. Second, I restrict the sample to women who are observed to live at least to 1901. Death dates are only observable for women who are on the pension at the time of their death. As such, all remarried women in this second sample had to have applied to be restored to the pension roles under the act of 3 March 1901; all unmarried women in the sample would have to have remained on the pension roles for the entire sample period. This restriction forces information on marital status to come from the same place for all women; moreover, it eliminates any systematic health differences between women who remarry before or after receiving the pension.

To mitigate concerns about pension fraud, I restrict the sample to women who are successfully linked to the census of 1870 or 1880, and whose marital status is corroborated by these links. Women have an incentive to lie to the pension board about marital status; however, there should be no such incentive to lie to census enumerators. While this does not entirely eliminate the possibility of fraud, the linked sample should contain a larger proportion of women who accurately report remarriage information to the pension bureau than the baseline sample. If hidden remarriages are biasing the estimated effect of the pension away from zero, this sample restriction should cause the estimate to decrease in magnitude. As an additional robustness test, I omit outliers in the distribution of time between widowhood and initial application, time to remarriage, and processing time. Finally, I restrict the sample to women whose husbands died during the war. Dying during the war is arguably more random than failing to recover from a non-life-threatening injury or disease contracted during the war, so it is worth verifying that the results are robust to this sample restriction.

I estimate the proportional hazards model described earlier under these sample restrictions, and the results appear in Table $6 .{ }^{21}$ The baseline

\footnotetext{
${ }^{21}$ Only results that do not correct for unobserved heterogeneity are reported; results that do correct for unobserved heterogeneity look very similar.
} 
TABLE 6

SENSITIVITY OF ESTIMATES TO SAMPLE RESTRICTIONS

Panel A. Baseline

\begin{tabular}{lccc}
\hline Pension & $-0.269^{*}$ & $-0.545^{* * *}$ & $-0.299^{*}$ \\
& $(0.154)$ & $(0.170)$ & $(0.155)$ \\
Pension X age at widowhood & & $-0.061^{* * *}$ & \\
& & $(0.017)$ & $-0.166^{* *}$ \\
Pension X number of children & & $(0.067)$ \\
& & & -1851.558 \\
Log likelihood & -1854.559 & -1847.944 & 688 \\
Observations & 688 & 688 & \\
\hline
\end{tabular}

Panel B. Women with Children under 16

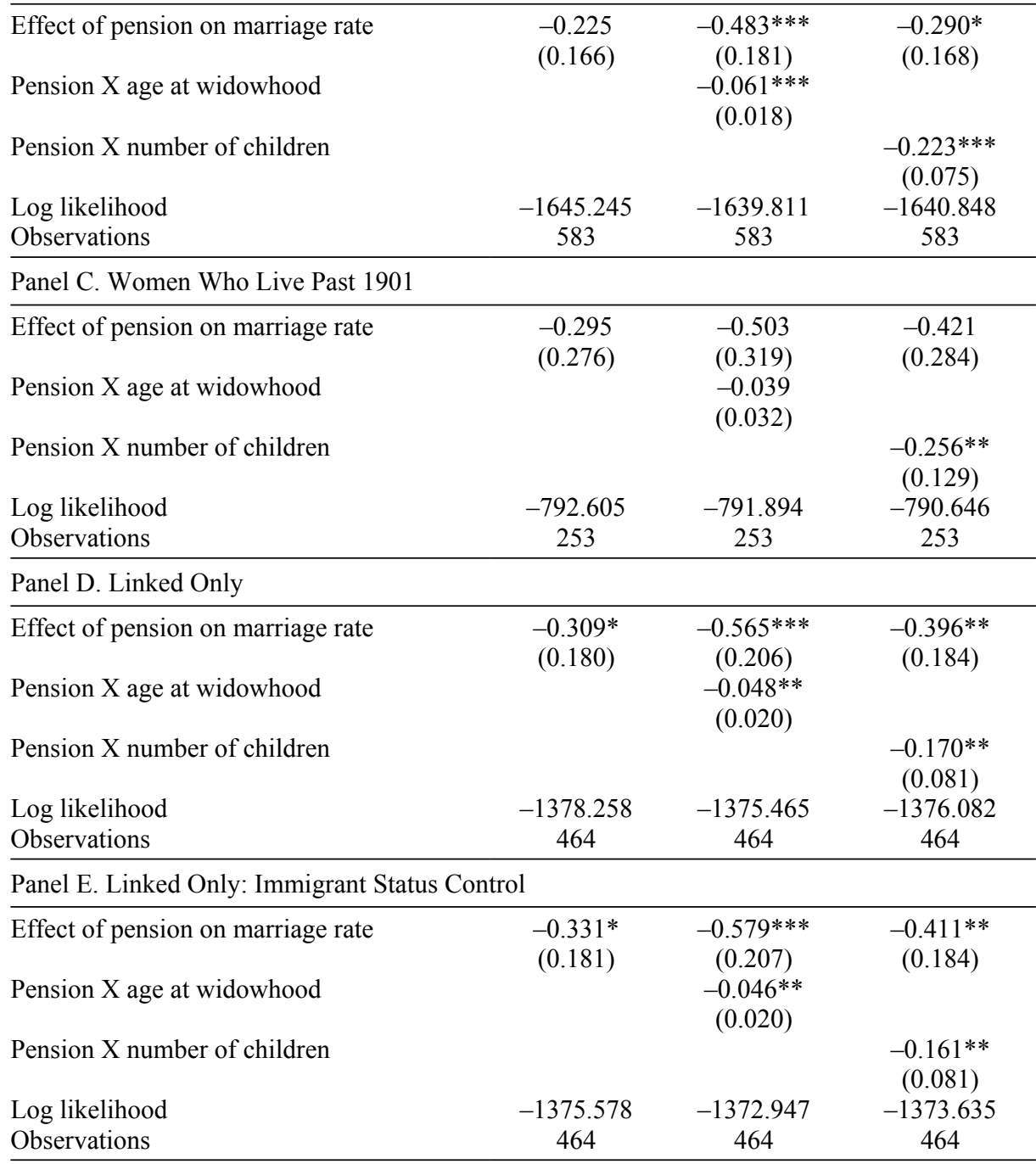


TABLE 6 (CONTINUED)

SENSITIVITY OF ESTIMATES TO SAMPLE RESTRICTIONS

Panel F. Omitting Outliers in Processing Time, Time to Remarriage, and Time to Application

\begin{tabular}{|c|c|c|c|}
\hline Effect of pension on marriage rate & $\begin{array}{c}-0.354 * * \\
(0.163)\end{array}$ & $\begin{array}{c}-0.639 * * * \\
(0.177)\end{array}$ & $\begin{array}{c}-0.366^{* *} \\
(0.164)\end{array}$ \\
\hline Pension $\mathrm{X}$ age at widowhood & & $\begin{array}{c}-0.068 * * * \\
(0.018)\end{array}$ & \\
\hline Pension X number of children & & & $\begin{array}{c}-0.179 * * * \\
(0.069)\end{array}$ \\
\hline Log likelihood & -1591.584 & -1587.797 & -1591.554 \\
\hline Observations & 620 & 620 & 620 \\
\hline \multicolumn{4}{|l|}{ Panel G. Husband Died During War } \\
\hline Effect of pension on marriage rate & $\begin{array}{l}-0.246 \\
(0.181)\end{array}$ & $\begin{array}{c}-0.448^{* *} \\
(0.189)\end{array}$ & $\begin{array}{l}-0.263 \\
(0.181)\end{array}$ \\
\hline Pension $\mathrm{X}$ age at widowhood & & $\begin{array}{c}-0.059 * * * \\
(0.020)\end{array}$ & \\
\hline Pension X number of children & & & $\begin{array}{l}-0.116 \\
(0.081)\end{array}$ \\
\hline Log likelihood & -1338.634 & -1334.480 & -1337.623 \\
\hline Observations & 502 & 502 & 502 \\
\hline
\end{tabular}

Notes: Results from model with no correction for unobserved heterogeneity. All specifications include the full set of controls from Table 4; see notes to this table for explanation. The top panel replicates the baseline results. Panel B restricts the sample to women who have children under 16 at the time of initial pension application. Panel $\mathrm{C}$ restricts the sample to women who live at least to 1901. Panel D restricts the sample to women whose marital status is verified independently by links to the Federal Census. Panel E uses the sample from panel D, and includes a control for immigrant status. Panel F omits women who applied for a pension more than two years after widowhood, remarried after more than 15 years, or took more than 15 years to process a pension claim. Panel G restricts the sample to women widowed during the war.

Sources: Fogel (2000) and Widows' Pension Database (see text for details).

results are repeated in panel $\mathrm{A}$. Results that include interactions between pension status and the widow's age and number of children are also included. The remaining panels contain results under the sample restrictions outlined previously. The average effect of the pension is not particularly sensitive to these sample restrictions; however, the estimate often fails to achieve statistical significance, even at the 10 percent level. The truly robust results are the interaction effects with age and number of children. Notably, restricting the sample to those linked to the census causes the estimated effect of the pension to increase rather than decrease in magnitude, suggesting that fraud is not significantly biasing my results.

\section{CONCLUSION}

This article documents the large effect Civil War pension income had on the marital outcomes of Union Army widows during the mid-nineteenth century. Having a claim granted lowered the rate of remarriage 
by 25 percent overall, implying an increase in the median time to remarriage of 3.5 years. For women over 32, the pension lowered the rate of remarriage by more than 40 percent. My estimates imply that, if a typical 32-year-old widow immediately received a pension, this would reduce the probability that she remarries within ten years by 20 percentage points relative to an identical widow with no pension.

The heterogeneity in the effect of the pension is consistent with the hypothesis that the pension lowered marriage rates by making women more selective in the marriage market, or by reducing the effort they spent searching for husbands. Older women with more children may have had less favorable marriage prospects, which could mean that they needed to expend more effort at the margin to procure an acceptable match. This should generate a larger response, in terms of search effort, to the increase in utility the pension afforded these women. Similarly, if younger women with fewer children faced a more favorable distribution of match qualities, their reservation match qualities may have been closer to the lower tail of this distribution. This should cause pension-induced changes in the probability of encountering a suitable match to be smaller for younger women.

While these results are not shown, an examination of linked census data demonstrates that women who married before and after receiving a pension did not marry systematically different spouses. While this may reflect the impossibility of measuring match quality with available census data, it may also be that the pension lowered the rate of remarriage by allowing women to opt out of remarriage entirely, rather than allowing them to wait longer for better matches; this would make sense if there was limited variation in match quality available to individual women. It may also be that the primary driver of the change in marriage rates was effort expended by the widow on finding a new husband.

Overall, these results paint a bleak picture of the conditions Union Army widows faced in the aftermath of the Civil War. Given that my sample consists of widows who applied for pensions, it is likely comprised of women who faced the worst marriage prospects; for instance, the pool of pension applicants is poorer on average than the pool of non-applicants. It is nonetheless striking that these women-particularly older widows with more children-were entering into marriages that were not preferable to an income stream barely above subsistence level. These results suggest that the Civil War may have created adverse marriage market conditions for women, even if it did not meaningfully affect the number of women who were able to marry. More broadly, these results point to 
some of the unseen welfare benefits of social provision, and of developments in the labor market that have afforded women alternatives to marriage.

\section{REFERENCES}

Abbring, Jaap H., and Gerard J. Van den Berg. "The Nonparametric Identification of Treatment Effects in Duration Models." Econometrica 71, no. 5 (2003a): 1491-517. - "The Identifiability of the Mixed Proportional Hazards Competing Risks Model." Journal of the Royal Statistical Society, Series B 65, no. 3 (2003b): 701-10.

_. "The Effect of Unemployment Insurance Sanctions on the Transition Rate from Unemployment to Employment.” Economic Journal 115, no. 505 (2005): 602-30. Abramitzky, Ran, Leah Platt Boustan, and Katherine Eriksson. "Europe's Tired, Poor, Huddled Masses: Self-Selection and Economic Outcomes in the Age of Mass Migration." American Economic Review 102, no. 5 (2012): 1832-56.

Abramitzky, Ran, Adeline Delavande, and Luis Vasconcelos. "Marrying Up: The Role of Sex Ratio in Assortative Mating." American Economic Journal: Applied Economics 3, no. 3 (2011): 124-57.

Baker, Michael, Emily Hanna, and Jasmin Kantarevic. "The Married Widow: Marriage Penalties Matter!" Journal of the European Economic Association 2, no. 4 (2004): 634-64.

Becker, Gary S. A Treatise on the Family. Cambridge: Harvard University Press, 1991. Blanck, Peter, and Chen Song. "Civil War Pension Attorneys and Disability Politics." Journal of Law Reform 35, no. 4 (2002): 137-217.

Blau, Francine D., Lawrence M. Kahn, and Jane Waldfogel. "Understanding Young Women's Marriage Decisions: The Role of Labor and Marriage Market Conditions." Industrial and Labor Relations Review 53, no. 4 (2000): 624-47.

Brien, Michael J., Stacy Dickert-Conlin, and David A. Weaver. "Widows Waiting to Wed?" Journal of Human Resources 39, no. 3 (2004): 585-623.

Chetty, Raj. "Moral Hazard versus Liquidity and Optimal Unemployment Insurance." Journal of Political Economy 116, no. 2 (2008): 173-234.

Costa, Dora. "Pensions and Retirement: Evidence from Union Army Veterans." Quarterly Journal of Economics 110, no. 2 (1995): 297-319.

- "Displacing the Family: Union Army Pensions and Elderly Living Arrangement." Journal of Political Economy105, no. 6 (1997): 1269-92.

Easterlin, Richard A. "Relative Economic Status and the American Fertility Swing." In Family Economic Behavior: Problems and Prospects, edited by E.B. Sheldon,170 223. Philadelphia: Lippincott, 1973.

Eli, Shari. "Income Effects on Health: Evidence from Union Army Pensions." Journal of Economic History 75, no. 2 (2015): 448-78.

Fogel, Robert W. Public Use Tape on the Aging of Veterans of the Union Army: Military, Pension, and Medical Records, 1860-1940, Version M-5. Center for Population Economics, University of Chicago Graduate School of Business, and Department of Economics, Brigham Young University, 2000. 
Gans, Joshua S., David H. Hsu, and Scott Stern. "The Impact of Uncertain Intellectual Property Rights on the Market for Ideas: Evidence from Patent Grant Delays." Management Science 54, no. 5 (2008): 982-97.

Glasson, William H. History of Military Pension Legislation in the United States. Ph.D. diss., Columbia University, 1900.

- Federal Military Pensions in the United States. New York: Oxford University Press, 1918.

Goldin, Claudia. Understanding the Gender Gap: An Economic History of American Women. New York: Oxford University Press, 1990.

_. "Career and Family: College Women Look to the Past." In Gender and Family Issues in the Workplace, edited by Francine Blau and Ronald G. Ehrenberg, 20-58. New York: Russell Sage Foundation, 1997.

Gould, Eric D., and M. Daniele Paserman. "Waiting for Mr. Right: Rising Inequality and Declining Marriage Rates." Journal of Urban Economics 53, no. 2 (2003): 257-81.

Grambsch, Patricia M., and Terry M. Therneau. "Proportional Hazards Tests and Diagnostics based on Weighted Residuals." Biometrika 81, no. 3 (1994): 515-26.

Hacker, J. David. "Economic, Demographic, and Anthropometric Correlates of First Marriage in the Mid-Nineteenth-Century United States." Social Science History 32, no. 3 (2008): 307-45.

Hacker, J. David, Libra Hilde, and James Holland Jones. "The Effect of the Civil War on Southern Marriage Patterns.” Journal of Southern History 76, no. 1 (2010): 39-70.

Haines, Michael R. "Long-Term Marriage Patterns in the United States from Colonial Times to Present." History of the Family 1 (1996): 15-39.

Haines, Michael R. and Inter-university Consortium for Political and Social Research. Historical, Demographic, Economic, and Social Data: The United States, 1790-2002 [Computer file]. ICPSR02896-v3. Ann Arbor, MI: Inter-university Consortium for Political and Social Research [distributor], 2010-05-21. doi:10.3886/ICPSR02896

Hankins, Scott, and Mark Hoekstra. "Lucky in Life, Unlucky in Love? The Effect of Random Income Shocks on Marriage and Divorce." Journal of Human Resource 46, no. 2 (2011): 403-26.

Heckman, James J., and Burton Singer. "A Method for Minimizing the Impact of Distributional Assumptions in Econometric Models for Duration Data." Econometrica 52, no. 2 (1984): 271-320.

Jensen, Robert. "Do Labor Market Opportunities Affect Young Women's Work and Family Decisions? Experimental Evidence from India." Quarterly Journal of Economics 137, no. 2 (2012): 753-92.

Linares, Claudia. "The Civil War Pension Law." Center for Population Economics Working Paper No. 2001-6, Chicago, 2001.

Loughran, David. "The Effect of Male Wage Inequality on Female Age at First Marriage." Review of Economics and Statistics 84, no. 2 (2002): 237-50.

Margo, Robert A. Wages and Labor Markets in the United States, 1820-1860. Chicago: University of Chicago Press, 2000.

Moehling, Carolyn. "Broken Homes: The 'Missing' Children of Single Mothers in the 1910 Federal Census." Journal of Interdisciplinary History 33, no. 2 (2002): 205-33. 
Monohan, Thomas P. The Pattern of Age at Marriage in the United States vol. 2. Philadelphia: Stephenson Brothers, 1951.

Mortenson, Dale T. "Job Search and Labor Market Analysis." In Handbook of Labor Economics, edited by O. Ashenfelter and R. Layard, 849-920. Amsterdam: North Holland, 1986.

Munch, Jakob R., Michael Rosholm, and Michael Svarer. "Home Ownership, Job Duration, and Wages," Journal of Urban Economics 63, no. 1 (2008): 130-45.

Oliver, John William. "History of the Civil War Military Pensions." Bulletin of the University of Wisconsin Historical Series 4, no. 844 (1917): 1-120.

Olivetti, Claudia, and M. Daniele Paserman. "In the Name of the Son (and the Daughter): Intergenerational Mobility in the United States: 1850-1930." American Economic Review 105, no. 8 (2015): 1-31.

Preston, Samuel H., and Michael Haines. Fatal Years: Child Mortality in Late Nineteenth Century America. Princeton: Princeton University Press, 1991.

Rogerson, Richard, Robert Shimer, and Randall Wright. "Search-Theoretic Models of the Labor Market: A Survey.” Journal of Economic Literature 43, no. 4 (2005): 959-88.

Rosenzweig, Mark R. "Welfare, Marital Prospects, and Nonmarital Childbearing." Journal of Political Economy 107, no. 56 (1999): 3-32.

Ruggles, Steven J., Trent Alexander, Katie Genadek, et al. Integrated Public Use Microdata Series: Version 5.0 [Machine-readable database]. Minneapolis: University of Minnesota, 2010.

Salisbury, Laura. "Selective Migration, Wages, and Occupational Mobility in Nineteenth Century America." Explorations in Economic History 53 (2014): 40-63.

Schoenfeld, David. "Chi-Squared Goodness-of-Fit Tests for the Proportional Hazards Regression Model.” Biometrika 67, no. 1 (1980): 145-53.

Schwartzberg, Beverly. "'Lots of them Did That': Desertion, Bigamy, and Marital Fluidity in Late-Nineteenth-century America." Journal of Social History 37, no. 3 (2004): 573-600.

Skocpol, Theda. Protecting Soldiers and Mothers: The Political Origins of Social Policy in the United States. Cambridge: Harvard University Press, 1995.

Song, Chen. "Filing for the Union Army Pension: A Summary from Historical Evidence." Unpublished Paper, Center for Population Economics, University of Chicago, 2000.

United States Pension Bureau. Annual Report of the Commissioner of Pensions to the Secretary of the Interior for the Year Ending June 30, 1883. Washington: Government Printing Office, 1883.

- Annual Report of the Commissioner of Pensions to the Secretary of the Interior for the Year Ending June 30, 1872. Washington: Government Printing Office, 1872.

- Annual Report of the Commissioner of Pensions to the Secretary of the Interior for the Year Ending June 30, 1864. Washington: Government Printing Office, 1864.

Vinovskis, Maris. "Have Social Historians Lost the Civil War? Some Preliminary Demographic Speculations.” Journal of American History 76, no. 1 (1989): 3458 . 
Wanamaker, Marianne. "Industrialization and Fertility in the Nineteenth Century: Evidence from South Carolina." Journal of Economic History 72, no. 1 (2012): 168-96.

Weiss, Yoram. "The Formation and Dissolution of Families: Why Marry? Who Marries Whom? And What Happens Upon Divorce?" Handbook of Population and Family Economics 1 (1997): 81-123.

Widow's Certificate No. 8,336. Jonathan Timberman, Private, Company I, 12th New York Infantry. Case Files of Approved Pension Applications of Widows and Other Dependents of Civil War Veterans, ca. 1861 - ca. 1910. Records of the Department of Veterans' Affairs, Record Group 15. National Archives Building, Washington, DC. Digital Images, "Civil War Widows' Pensions," fold3.com.

Widow's Certificate No. 6,916. William Matthews, Private, Company C, 98th New York Infantry. Case Files of Approved Pension Applications of Widows and Other Dependents of Civil War Veterans, ca. 1861 - ca. 1910. Records of the Department of Veterans' Affairs, Record Group 15. National Archives Building, Washington, DC.

Widow's Certificate No. 23,539. Andrew Van Buren, Private, Company E, 100th New York Infantry. ----. 